Boris Lukovnjak: Analiza rezultata Europskoga zdravstvenoga potrošačkog indeksa od 2014. do 2017. s posebnim osvrtom na pokazatelje preventive

Izlaganje sa skupa

Primljeno: 25. IV. 2019.

Prihvaćeno: 25. XI. 2019.

UDK

https://doi.org/10.33604/sl.13.25.8

614.2(4-67 EU:497.5)

616-084(4-67 EU:497.5)"2014/2017"

\title{
Analiza rezultata Europskoga zdravstvenoga potrošačkog indeksa od 2014. do 2017. - s posebnim osvrtom na pokazatelje preventive
}

\author{
Boris Lukovnjak \\ Udruga poslodavaca u zdravstvu Hrvatske, Zagreb \\ boris.lukovnjak@roche.com
}

SAŽETAK: U radu su, na temelju analize istraživanja koje je pod nazivom Europski zdravstveni potrošački indeks (Euro Health Consumer Index - EHCI) provela renomirana švedska tvrtka Health Consumer Powerhouse, uspoređeni mjerljivi pokazatelji kvalitete i učinkovitosti zdravstvene skrbi u Republici Hrvatskoj s ostalim zemljama Europe. Spomenuta tvrtka svake godine objavljuje novu ediciju EHCI-ja kojom prati kretanja pojedinih pokazatelja ili cjelina pokazatelja u svakoj zemlji. S obzirom na tekovinu Andrije Štampara i njegovih istomišljenika, Hrvatska je u europskim i svjetskim okvirima prepoznata kao pionir postojećega europskog modela primarne zdravstvene zaštite i preventivnih aktivnosti. Zbog nedovoljnih financijskih ulaganja te nesustavnoga pristupa edukaciji populacije, Hrvatska je u spomenutoj analizi najlošije pokazatelje zdravstvene zaštite ostvarila upravo u području preventive. Istaknuti su kao važni i farmakoekonomski učinci ulaganja u prevenciju i primarnu zdravstvenu zaštitu jer je općepoznato kako je jedna kuna uložena u preventivu ekvivalentna iznosu od deset kuna uloženih u kurativu.

Ključne riječi: preventiva; Europski zdravstveni potrošački indeks; primarna zdravstvena zaštita

\section{Uvod}

S obzirom na to da smo 2016. u radu »Stanje preventive u današnjoj Europi s osvrtom na Hrvatsku« napravili snimku trenutačnoga stanja pokazatelja Republike Hrvatske i ostalih europskih zemalja prema rezultatima Europskoga zdravstvenoga potrošačkoga indeksa (Euro Health Consumer Index - EHCI) za 2015. godinu, u ovome radu prikazat ćemo trend kretanja rezultata praćenih parametara tijekom godina. Naravno, ključni dio analize bit će usmjeren upravo na pokazatelje preventive. Prije nego što počnemo detaljnije analizirati pojedine parametre te skupine parametara, nužno je predstaviti ključne odrednice metodologije provedene analize.

Tvrtka Health Consumer Powerhouse analizira pojedine indikatore svrstane u određene skupine koje se prate i, s obzirom na razinu ostvarene kvalitete pojedino- 
ga indikatora, svakoj se zemlji dodjeljuje težinska ocjena za pojedini indikator te, kao prosjek indikatora, i ocjena za skupinu, iz koje se potom izračunava ukupna ocjena za pojedinu zemlju po kojoj se sve zemlje rangiraju.

Komprimirano izvješće EHCI-ja temelji se na 46 indikatora, svrstanih u šest ključnih skupina:

1. Prava i informiranost pacijenata,

2.Dostupnost zdravstvene zaštite,

3.Ishodi liječenja,

4.Opseg dostupnih zdravstvenih usluga

5.Prevencija

6.Farmaceutika

Ukupan rezultat Republike Hrvatske mijenjao se tijekom godina, djelomično i sukladno promjeni metodologije samoga EHCI-ja. U 2017. godini Republika Hrvatska zauzela je 26. mjesto u odnosu na 35 analiziranih zemalja, što predstavlja lošije pozicioniranje s obzirom na 2016. godinu, kada je bila na solidnom 19. mjestu. Pri interpretaciji tih rezultata moramo biti svjesni toga da je Republika Hrvatska po financijskom ulaganju za zdravstvo na samom dnu Europske unije te da su navedeni rezultati Europskoga zdravstvenoga potrošačkoga indeksa zasigurno u direktnoj korelaciji sa znatno nižom razinom ulaganja u zdravstvo u Republici Hrvatskoj nego u drugim zemljama Europske unije.

\section{Analiza indikatora i skupina}

Prije nego što krenemo na analizu pojedinačnih indikatora u skupini »Prevencija«, važno je istaknuti kako je u određenim indikatorima te skupinama Republika Hrvatska ostvarila izvrsne rezultate, imajući uvijek na umu razinu ulaganja u zdravstvenu zaštitu. S obzirom na naš model financiranja zdravstvenoga sustava, koji je pretežito Bismarckov (model međugeneracijske solidarsnosti), a tek djelomično Beveridgeov (prikupljanje sredstava kroz poreze), Republika Hrvatska i danas ima visoko učešće javnih zdravstvenih ustanova i djelatnika u ukupnom broju pružatelja zdravstvene skrbi. S obzirom na to da javna sredstva čine više od $80 \%$ ukupne potrošnje za zdravstvo te da se Republika Hrvatska po ovom indikatoru od 2014. do 2017. godine kretala između 7. i 5. mjesta, moramo istaknuti kako je učešće »privatne« zdravstvene potrošnje u Republici Hrvatskoj još u fazi razvoja te da će daljnjim razvojem osiguravajućih društava u segmentu dodatnoga zdravstvenog osiguranja taj dio izdvajanja zasigurno porasti. 
Jedan od segmenata u kojem je Republika Hrvatska napravila značajan iskorak u proteklih 10-ak godina jest razvoj e-zdravstva, koje predstavlja neizbježan smjer kako za Europu tako i za svijet, a Republika Hrvatska je svojim inovativnim rješenjima kao što su e-recept i e-uputnica postala predvodnica toga pokreta u Europi. Dostupnost e-recepta jedan je od indikatora koji je tijekom godina praćen u ovoj analizi te s ponosom možemo zaključiti da je u 2017. prema navedenom indikatoru Republika Hrvatska na 1. mjestu.

Dostupnost primarne zdravstvene zaštite putem mreže domova zdravlja, koncesionara, ljekarni i Zavoda za javno zdravstvo predstavlja temelj kvalitetne zdravstvene skrbi. S obzirom na geografsku specifičnost Republike Hrvatske vrlo je teško ostvariti jednako kvalitetnu i dostupnu zdravstvenu zaštitu u svakom selu ili na svakom otoku. Ponekad možda nismo ni sami posve svjesni razine dostupnosti zdravstvene zaštite u Republici Hrvatskoj u odnosu na druge zemlje, ali je više od same dostupnosti važna i ujednačenost kvalitete pružanja iste u svakom dijelu naše zemlje. Po indikatoru dostupnosti liječnika primarne zdravstvene zaštite, Republika Hrvatska je u posljednje četiri godine u samom vrhu, dok je u 2017. godini zabiljě̌ila najlošiju poziciju (10. mjesto).

U skupinu indikatora prevencije EHCI analizirao je sljedeće indikatore:

1. Infant 8 disease vaccination (procijepljenost djece od 8 bolesti)

2. Blood pressure (krvni tlak)

3. Smoking prevention (prevencija pušenja)

4. Alcohol (alkohol)

5. Physical activity (tjelesna aktivnost)

6. HPC vaccination (HPV procijepljenost)

7. Traffic deaths (smrti uzrokovane prometnim nesrećama)

O svih navedenih indikatora, Republika Hrvatska je pozitivnu ocjenu ostvarila jedino u indikatoru HPV procijepljenosti, prosječnu ocjenu u procijepljenosti djece od osam bolesti te smrti uzrokovanih prometnim nesrećama. U ostalim indikatorima prevencije Republika Hrvatska dobila je negativne ocjene.

Antivakcinacijske kampanje u Europi, pa tako i u Republici Hrvatskoj, snažan su i agresivan trend koji propitkuje neka od temeljnih načela zdravstvenih politika u svijetu koje su tijekom godina rezultirale znatnim produljenjem prosječnoga trajanja života te iskorjenjivanjem određenih nekoć smrtonosnih bolesti. Antivakcinacijski trend u Republici Hrvatskoj dobio je veliku medijsku pozornost te je čak postao i fokus određenih političkih opcija. Nedavna pojavnost nekih »starih « bolesti u određenim dijelovima Republike Hrvatske dokazala je zapanjujuće razmjere ova- 
kvih antivakcinacijskih aktivnosti. EHCI tijekom godina prati procijepljenost djece i dojenčadi na osam bolesti:

1. Tetanus

2. Hripavac

3. Poliomijelitis

4. Gripa B

5. Hepatitis B

6. Ospice

7. Zaušnjaci

8. Rubeola

U 2014. i 2015. godini Republika Hrvatska je po navedenom indikatoru zauzela mjesto u prvoj trećini zemalja s najvišom stopom procijepljenosti, dok je u 2016. godine zabilježen drastičan pad na 24. mjesto. Nepoznato je je li naveden negativan trend posljedica isključivo aktualne antivakcinacijske kampanje ili je i posljedica promjena metodologije ili kvalitete analiziranih podataka. U konačnici, neovisno o razlogu navedenoga negativnog trenda, nužno je kontinuirano isticati važnost cijepljenja djece kao osnovu povijesnih borbi znanosti s tada neizlječivim bolestima te novim zakonskim rješenjima regulirati učinke i posljedice necijepljenja.

Vrlo negativno rangiranje Republike Hrvatske $\mathrm{u}$ indikatoru prevalencije povišenoga tlaka otkriva temeljne javnozdravstvene probleme našega društva kao što su: pušenje, alkohol, nezdrava hrana i stres. Prema ovom indikatoru u 2017. godini smjestili smo se na samo dno tablice (32-35. mjesto), zajedno s Estonijom, Latvijom i Bugarskom. Analizirajući ove rezultate, također možemo istaknuti direktnu povezanost između iznosa koji se izdvaja za zdravstvenu zaštitu i navedenih rezultata. Istaknute su zemlje također na samom dnu po izdvajanju za zdravstvenu zaštitu po glavi stanovnika. U posljednjih nekoliko godina, uz onkološke, kardiovaskularne su bolesti najzastupljeniji uzrok smrti u Republici Hrvatskoj.

Republika Hrvatska često se naziva »najsportskijom nacijom na svijetu«, a hrvatski su sportaši najpopularniji ambasadori svoje države u svijetu. Sport, uz svoju ekonomsku i promidžbenu vrijednost, ima zasigurno i zdravstvenu vrijednost jer je fizička aktivnost jedan od temelja zdravoga života. Analizirajući sate tjelesnoga odgoja u školama kao jedan od indikatora, možemo zaključiti da smo od 2014. godine »stabilno loši«, odnosno konstantno smo na 28. mjestu. O ovom poražavajućem rezultatu ne treba diskutirati isključivo kroz prizmu organizacije zdravstvenoga sustava i prevencije, već kroz nužnost reforme školskoga sustava i vrijednosti koje se uče kroz školovanje. Uz navedeno, poražavajući je i broj škola u Republici Hrvatskoj s 
vlastitom sportskom dvoranom, opremljenom za sigurnu fizičku aktivnost svojih učenika. Grad Zagreb kao glavni grad Republike Hrvatske raspolaže sa svega nekoliko bazena, dok školske ustanove takav vid tjelesne aktivnosti niti ne provode. Zdravi stilovi života, učeni od »malih nogu«, predstavljaju izvrsnu podlogu za zdraviju Republiku Hrvatsku i njezine građane u budućnosti.

Uz zemlje kao što su Irska, Njemačka, Litva i Austrija, prednjačimo na europskoj ljestvici nacija po broju ispijenih litara alkohola po glavi stanovnika. Konzumacija alkohola u Republici Hrvatskoj postala je kulturološki prihvaćen dodatak svim oblicima zabave (koncerti, sportska natjecanja, razne proslave itd.). Možebitan važan čimbenik u izrazito visokoj konzumaciji alkohola u Republici Hrvatskoj jest i činjenica da Republika Hrvatska još nije u svoj porezni sustav integrirala poseban paket poreznih mjere kojima bi financijskim nametnima demotivirala građane prije svega od pušenja, ali i od prevelike konzumacije alkohola. Osobno smatram kako je najproblematičnija činjenica kako se s pretjeranom konzumacijom alkohola susrećemo u vrlo mladoj, ponekad i maloljetnoj populaciji, kojoj količina konzumiranoga alkohola predstavlja predmet kompeticije s drugim vršnjacima. Republika Hrvatska je u navedenom indikatoru u 2017. godini zauzela 29. mjesto od 35 promatranih zemalja.

Konzumacija duhanskih proizvoda segment je koji smo već donekle dotaknuli u komentarima prethodnoga indikatora konzumacije alkohola, ali s obzirom na to da konzumacija duhana predstavlja golemi problem hrvatskoga društva, u nastavku ćemo u nekoliko rečenica objasniti trenutačnu situaciju. Zajedno s drugim zemljama bivše Jugoslavije, kao što su Srbija, Makedonija i Slovenija, zauzimamo neslavni vrh ljestvice europskih pušačkih nacija. Prema neslužbenim podatcima iz medija, u Republici Hrvatskoj godišnje se proda čak 40 milijuna kutija cigareta, a svakodnevno puši čak 29\% stanovnika Republike Hrvatske. Povezujući pušenje s njegovim posljedicama i financijskim opterećenjem države u saniranju posljedica pušenja (kardiovaskularne bolesti, onkološke bolesti, npr. rak pluća, i dr.), jasno je kako pušenje nije isključivo zdravstveni problem, već je i važan financijski problem u upravljanju zdravstvenim sustavom. Ova je tema izrazito aktualizirana posljednjih godina, kada su Koalicija udruga u zdravstvu i Udruga poslodavaca u zdravstvu javnosti prezentirale svoj model tzv. zdravoga fonda. Postupnim povećanjem cijene cigareta na razinu prosjeka Europske unije dio pušača prestao bi pušiti, a dio novoga prihoda od povećanih cijena preusmjerio bi se u »zdravi fond«, koji bi osiguravao ta sredstva isključivo za zdravstvenu zaštitu. Plaćajući npr. tri kune više za svaku kutiju cigareta, konzument bi osigurao da u budućnosti on i njegova obitelj imaju mogućnost liječenja najučinkovitijom inovativnom onkološkom terapijom ukoliko dođe do onkološke bolesti kod konzumenta. Takav model svojevrsno je samoosiguravanje trenutačnoga štetnog ponašanja kako bi u budućnosti financijske okolnosti u zdravstvenom sustavu Republike Hrvatske mogle svakom pacijentu omogućiti najučinkovitiju terapiju za njegovu bolest. Zadovoljavajući su i trenutačni napori zdravstvene administracije 
na čelu s ministrom Kujundžićem koja je u novim zakonskim rješenjima predvidjela znatno povećanje cijene cigareta i alkoholnih pića s ciljem ostvarivanja dodatnoga prihoda zdravstvenom sustavu, čime bi se osigurala bolja skrb za naše pacijente.

\title{
Zaključak
}

Kontinuirana edukacija populacije te jačanje preventive, po uzorku na spoznaje i učenja prof. Andrije Štampara najbolji je model ostvarivanja boljih zdravstvenih ishoda uz optimizaciju financijskih sredstava. Činjenica kako je Republika Hrvatska u četiri analizirane godine EHCI-ja ostvarila najmanji broj bodova upravo na prevenciji apsolutno je poražavajuća. Otvoreno rečeno, ne postoji isključivi krivac za takve negativne pokazatelje, već mi kao društvo (zdravstvena administracija i korisnici zdravstvenih usluga) zajedno moramo raditi na edukaciji, prije svega onih najmlađih o važnosti zdravih stilova života. Ulaganjem dodatnih sredstava u primarnu zdravstvenu zaštitu i preventivne programe polučit ćemo znatne zdravstvene i ekonomske učinke jer je 1 kuna uložena u preventivu ekvivalentna prema iznosu od 10 kn uloženih u kurativu. Temeljem ovakvih poražavajućih pokazatelja, potrebno je podržati trenutačnu zdravstvenu administraciju u svojim nastojanjima da novom zakonskom regulativom smanji broj konzumenata alkoholnih pića i duhanskih proizvoda.

\section{AN ANALYSIS OF THE RESULTS OF THE EURO HEALTH CONSUMER INDEX FROM 2014 TO 2017 WITH SPECIAL REFERENCE TO PREVENTION INDICATORS}

\author{
Boris Lukovnjak \\ Association of Healthcare Employers of the Republic of Croatia, Zagreb \\ boris.lukovnjak@roche.com
}

\begin{abstract}
The key goal of this paper is to compare quality and efficiency indicators of the level of healthcare services in the Republic of Croatia to other EU countries using the "Euro Health Consumer Index (EHCI)' analysis, published by the renowned Swedish company Health Powerhouse. The mentioned company publishes a new edition of the EHCI annually, comparing trends of certain indicators or groups of indicators for each country. Due to the great heritage of Prof. Andrija Štampar and his followers, the Republic of Croatia is well-known in Europe and beyond as a pioneer of today's model of primary healthcare and preventive activities. Unfortunately, according to the EHCI, after years of insufficient funding and an unsupervised education model, the Croatia shows the worst scores precisely in the indicators related to prevention quality. It is also important to mention that the poor results of prevention-based activities have a strong pharmacoeconomic impact; it is widely known that one kuna invested in prevention and primary healthcare is equivalent to 10 kunas invested in hospital treatment.
\end{abstract}

Keywords: prevention; Euro Health Consumer Index; primary healthcare javnosti i prerađivati ga, uz obvezno navođenje autorstva, te ga koristiti samo u nekomercijalne svrhe. 